\title{
Amyloid-beta peptide degradation in cell cultures by mycoplasma contaminants
}

\author{
Haitian Zhao $^{1}$, Ute Dreses-Werringloer ${ }^{1}$, Peter Davies ${ }^{1,2}$ and \\ Philippe Marambaud*1,2
}

\begin{abstract}
Address: ${ }^{1}$ Litwin-Zucker Research Center for the Study of Alzheimer Disease, The Feinstein Institute for Medical Research, North Shore-LIJ Manhasset, NY, USA and 2Department of Pathology, Albert Einstein College of Medicine, Bronx, NY, USA

Email: Haitian Zhao - hzhao@nshs.edu; Ute Dreses-Werringloer - udreses@nshs.edu; Peter Davies - davies@aecom.yu.edu; Philippe Marambaud* - pmaramba@aecom.yu.edu

* Corresponding author
\end{abstract}

Published: 30 June 2008

BMC Research Notes 2008, I:38 doi:10.1 186/1756-0500-1-38

This article is available from: http://www.biomedcentral.com/1756-0500/I/38

(c) 2008 Zhao et al; licensee BioMed Central Ltd.

This is an Open Access article distributed under the terms of the Creative Commons Attribution License (http://creativecommons.org/licenses/by/2.0), which permits unrestricted use, distribution, and reproduction in any medium, provided the original work is properly cited.
Received: 29 February 2008

Accepted: 30 June 2008

\begin{abstract}
Background: Cell cultures have become an indispensable tool in Alzheimer's disease research for studying amyloid- $\beta(A \beta)$ metabolism. It is estimated that up to $35 \%$ of cell cultures in current use are infected with various mycoplasma species. In contrast with common bacterial and fungal infections, contaminations of cell cultures with mycoplasmas represent a challenging issue in terms of detectability and prevention. Mycoplasmas are the smallest and simplest self-replicating bacteria and the consequences of an infection for the host cells are variable, ranging from no apparent effect to induction of apoptosis.
\end{abstract}

Findings: Here we present evidence that mycoplasmas from a cell culture contamination are able to efficiently and rapidly degrade extracellular $A \beta$. As a result, we observed no accumulation of $A \beta$ in the conditioned medium of mycoplasma-positive cells stably transfected with the amyloid- $\beta$ precursor protein (APP). Importantly, eradication of the mycoplasma contaminant - identified as M. hyorhinis - by treatments with a quinolone-based antibiotic, restored extracellular $A \beta$ accumulation in the APP-transfected cells.

Conclusion: These data show that mycoplasmas degrade $A \beta$ and thus may represent a significant source of variability when comparing extracellular $A \beta$ levels in different cell lines. On the basis of these results, we recommend assessment of mycoplasma contaminations prior to extracellular $A \beta$ level measurements in cultured cells.

\section{Findings}

Alzheimer's disease (AD) is a progressive neurodegenerative disorder characterized by the presence of classical lesions in different brain regions of the neocortex and hippocampus [1]. Among these lesions, the amyloid plaques formed by the aggregation of amyloid- $\beta(\mathrm{A} \beta)$ peptides are prominent. The pathogenesis of the disease is complex and is driven by both environmental and genetic factors. Although most of the cases are sporadic with an obscure etiology, some forms of the disease are inherited and several genes are implicated in familial Alzheimer's disease (FAD). The understanding of the molecular basis of the disease gained significant knowledge with the observation that mutations in the three genes linked to early-onset 
autosomal dominant FAD, increase the production of a highly insoluble isoform of $A \beta$. Together, these observations support the so-called amyloid hypothesis in the pathogenesis of Alzheimer's disease [2,3]. Sequential endoproteolysis of the amyloid- $\beta$ precursor protein (APP) by the aspartic protease $\beta$-secretase/BACE1 and by the $\gamma$ secretase proteolytic complex leads to the production of $\mathrm{A} \beta$ (see Figure 1A). In an alternative non-amyloidogenic pathway, APP is endoproteolyzed within the $A \beta$ region by $\alpha$-secretase to produce the secreted sAPP $\alpha$ fragment (Figure $1 \mathrm{~A})[4,5]$.

Numerous primary and immortalized cell lines have been used to analyze APP processing and $\mathrm{A} \beta$ production in in vitro cultures. These cell culture systems have proven to be indispensable for the identification of pharmacological and genetic modifiers of APP metabolism prior to in vivo studies [6-8]. It is estimated that 15 to $35 \%$ of cell cultures in current use are infected with mycoplasmas [9]. With a diameter of about $0.2-0.4 \mu \mathrm{m}$, mycoplasmas are small, slow-growing bacteria that are generally unaffected by the antibiotics used against common bacteria and fungi. They can go undetected for long periods of time as the contaminated cells may grow normally and appear normal by light microscopy. Mycoplasma contaminations can however have negative effects, ranging from inhibition of metabolism and growth to induction of malignant transformation or apoptosis $[10,11]$. In this study, we show that mycoplasmas can degrade extracellular $A \beta$. These results indicate that mycoplasma contaminations can introduce an unsuspected source of variability in $A \beta$ level measurements in cultured cells.

\section{Characterization of extracellular $A \beta$ produced by APP- transfected cells}

The APP metabolites, sAPP $\alpha$ and A $\beta$, are readily detectable in the conditioned medium of HEK293 cells stably transfected with the human $\mathrm{APP}_{695}$ isoform (Figure $1 \mathrm{~B}$, first lane). As expected, treatment of these cells with the selective $\gamma$-secretase inhibitor, L-685,458, prevented A $\beta$ production and promoted accumulation of the APP intermediate fragments C99 and C83 (Figure 1B, second lane).

\section{Degradation of extracellular $A \beta$ by mycoplasma contaminants}

To first assess the effect of mycoplasmas on the levels of $\mathrm{A} \beta$ in cell culture, medium from mycoplasma-positive cells, detected by polymerase-mediated amplification of mycoplasma genomic DNA (Figure 2A), was diluted 1:1 with conditioned medium from APP-transfected HEK293 cells. The resulting mixture was then incubated at $37^{\circ} \mathrm{C}$ for different periods of time. Under these conditions, we observed a robust degradation of $A \beta$ after $1 \mathrm{hr}$ of incubation, while sAPP $\alpha$ levels were not affected (Figure 2B,
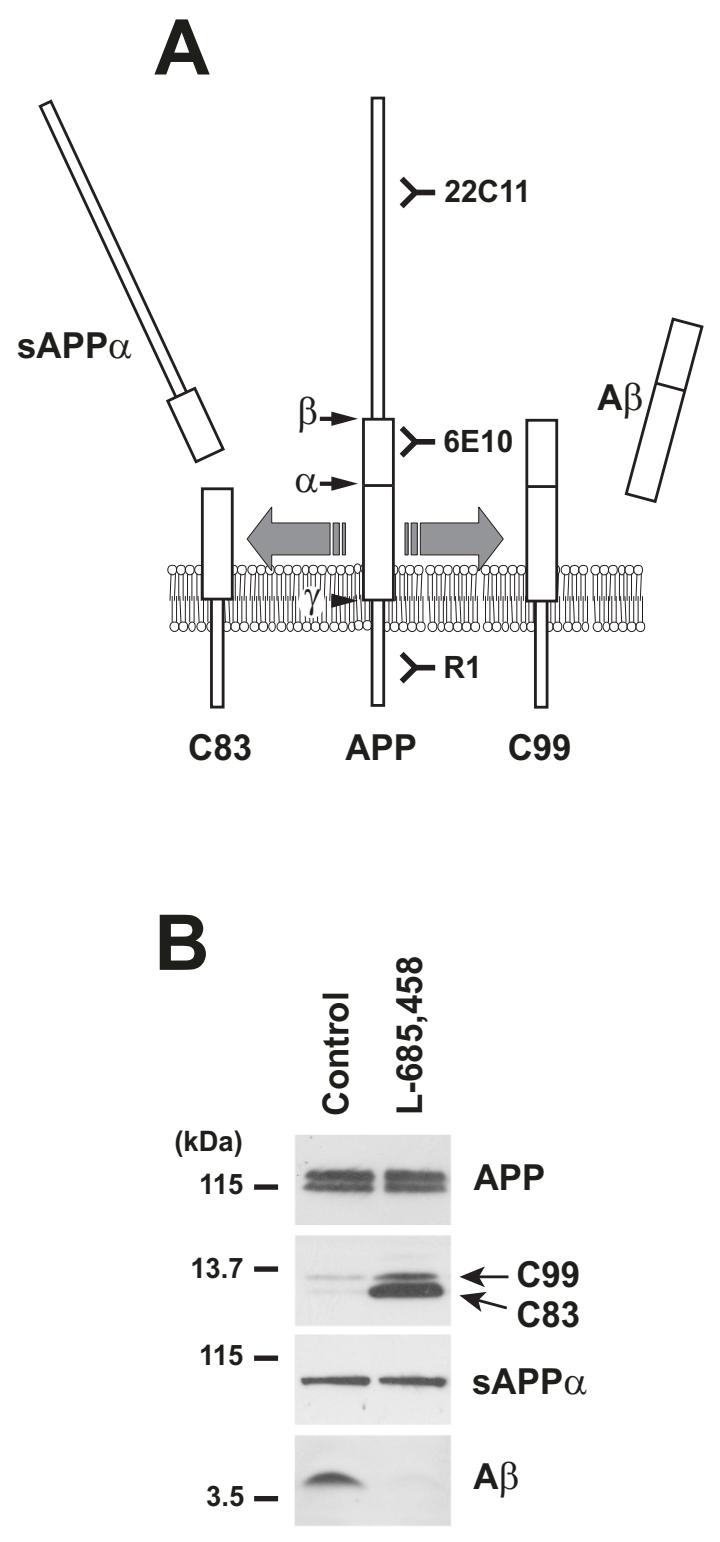

Figure I

APP processing. (A) Schematic representation of APP processing. APP undergoes two alternative endoproteolytic pathways. In the amyloidogenic pathway, APP is first cleaved by $\beta$-secretase $(\beta)$ to enable the production of the membrane bound C99 fragment. C99 is then cleaved in its intramembranous domain by $\gamma$-secretase $(\gamma)$ to release $A \beta$. In the non-amyloidogenic pathway, APP is cleaved by $\alpha$-secretase $(\alpha)$ to generate $\operatorname{APP} \alpha$ and the membrane bound C83 fragment. Immunogenic regions for the indicated anti-APP antibodies are shown. (B) HEK293 cells stably transfected with Swedish human APP ${ }_{695}$ CDNA [ 6] were incubated in the absence (Control) or presence of $\gamma$-secretase inhibitor (L-685,458, Calbiochem, I $\mu \mathrm{M}$ for $18 \mathrm{hrs}$ ). APP full-length (APP) and C-terminal fragments (C99 and C83) were analyzed by western blotting (WB) as described before [ I 6], using antibodies directed against APP N-terminal domain $(22 \mathrm{CII}$, Chemicon) and APP C-terminal domain (RI, provided by Dr. P.D. Mehta, see Ref. [ I 6]), respectively. Secreted SAPP $\alpha$ and A $\beta$ were analyzed by WB using anti-APP $1-17$ antibody (6EI0, Signet). Wild type and APP-transfected HEK293 cells were grown in DMEM plus $10 \%$ FBS, penicillin and streptomycin in $5 \% \mathrm{CO}_{2}$ at $37^{\circ} \mathrm{C}$. APP-transfected HEK293 cells were selected and maintained in $5 \mu \mathrm{g} / \mathrm{ml}$ puromycin. 

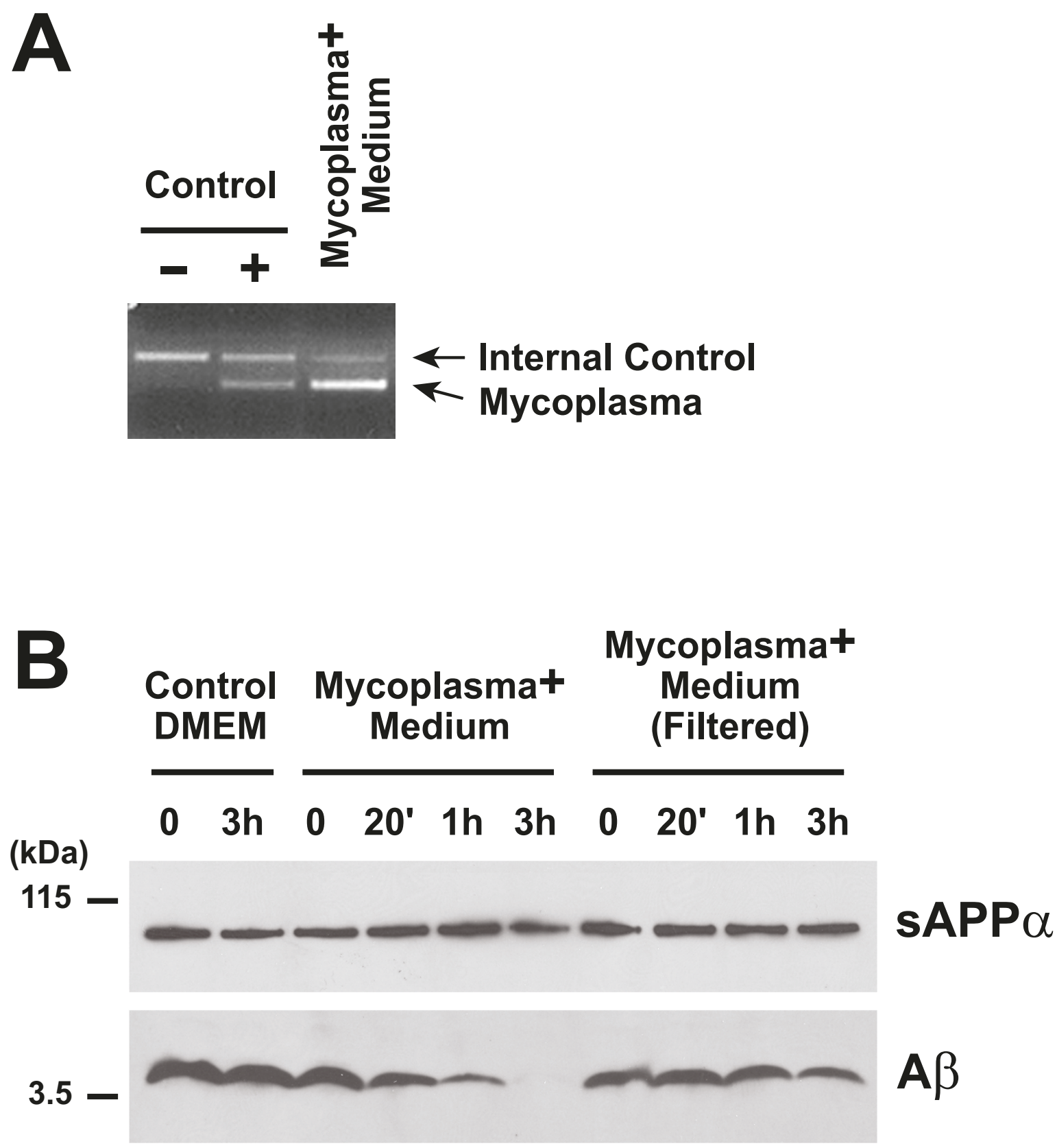

\section{$\begin{array}{llllllllll}1 & 2 & 3 & 4 & 5 & 6 & 7 & 8 & 9 & 10\end{array}$}

Figure 2

Degradation of extracellular $\mathbf{A} \beta$ by mycoplasma contaminants. (A) PCR amplification of mycoplasma genomic DNA was performed with an internal negative control template (Control -), a positive control template of M. orale genomic DNA $($ Control + ), or with medium from mycoplasma-positive HEK293 cell cultures (Mycoplasma+ Medium). Assay was carried out according to manufacturer's instructions (MycoSensor PCR Assay Kit, Stratagene). The changes in intensity of the internal control amplification are due to competition with the mycoplasma-specific PCR. (B) Medium from mycoplasma-positive cells was centrifuged at $1000 \times \mathrm{g}$ for 10 min to pellet the cell debris. Conditioned medium from APP-transfected HEK293 cells was diluted I:I with either fresh medium (Control DMEM), or with unfiltered (Mycoplasma+ Medium) or $0.2 \mu \mathrm{m}$ filtered [Mycoplasma+ Medium (Filtered)] medium from mycoplasma-positive cells. The resulting mixtures were incubated at $37^{\circ} \mathrm{C}$ for the indicated periods of time. SAPP $\alpha$ and $A \beta$ were analyzed by WB, as described in Figure IB. 
lanes 3-6). A $\beta$ degradation did not occur when fresh medium (Control DMEM) was mixed with $A \beta$-containing medium (Figure 2B, lanes 1 and 2). Importantly, reduction of the contaminant load by a $0.2 \mu \mathrm{m}$ filtration of the mycoplasma-positive medium prior to incubation, significantly prevented $A \beta$ degradation (Figure $2 B$, lanes 7-10). Together these data strongly indicate that mycoplasmas efficiently degrade $A \beta$ during normal cell culture conditions.

\section{Mycoplasma contamination prevents $A \beta$ accumulation in APP-transfected cells}

In order to confirm the detrimental effect of mycoplasma contamination on $A \beta$ accumulation in cell culture, we directly analyzed $A \beta$ levels produced by mycoplasma-pos-
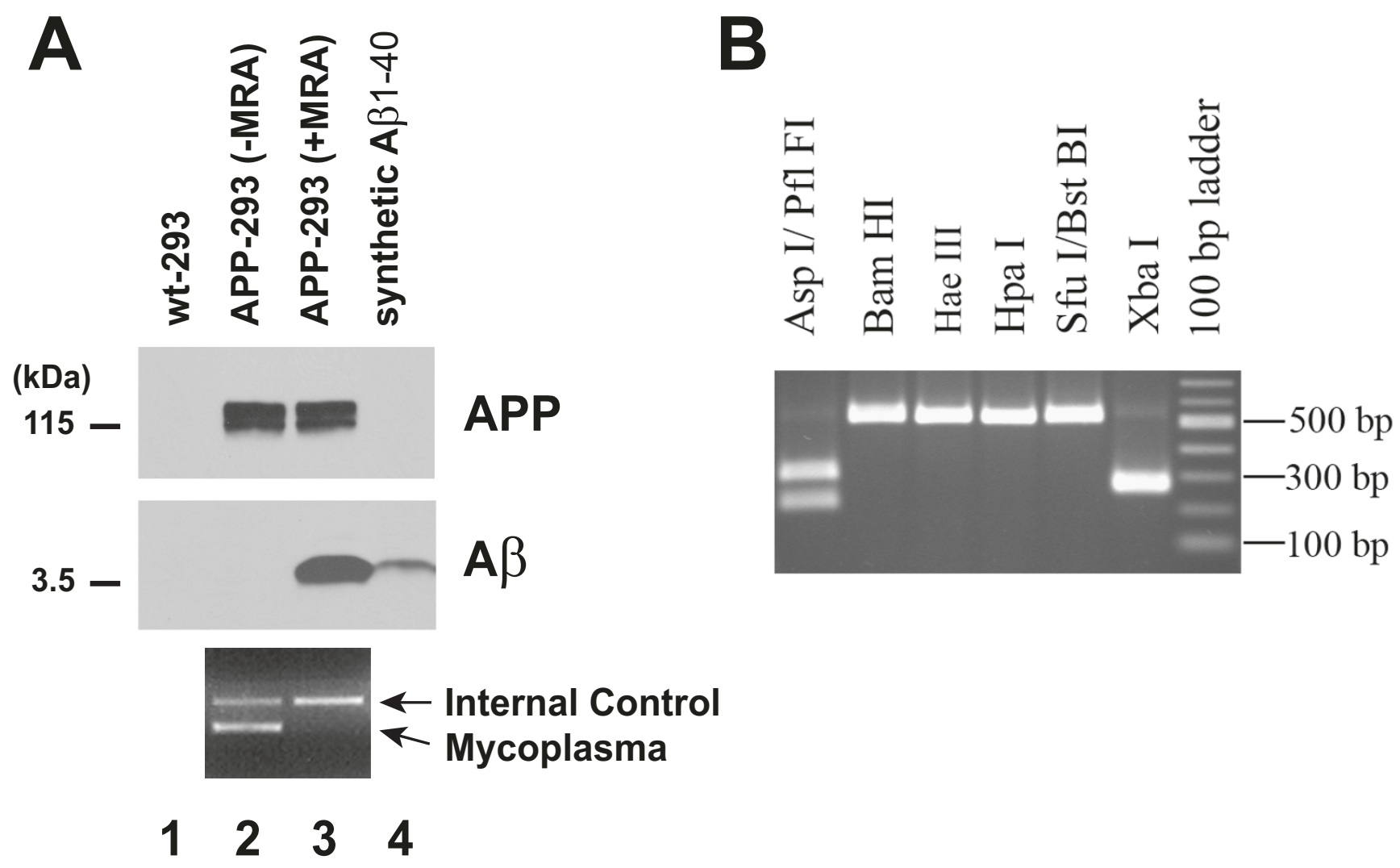

Figure 3

Mycoplasma eradication restored $A \beta$ accumulation in APP-transfected cells. (A) APP (first panel) and A $\beta$ (second panel) levels in wild-type (wt-293) and APP-transfected (APP-293) HEK293 cells were analyzed by WB, as described before. APP-293 cells were cultured for one week in the absence (-MRA) or presence (+MRA) of Mycoplasma Removal Agent (MRA, MP Biomedicals, Inc). Conditioned medium of untreated and treated APP-293 cells was analyzed by PCR for the presence of mycoplasma genomic DNA (lower panel), as described above. Twenty-five picograms of synthetic A $\beta$ I-40 (IBL-America) were loaded as a control (lane 4). (B) Determination of the mycoplasma species by restriction fragment polymorphism analysis of PCR products. The PCR product was digested with six different restriction endonucleases as indicated and separated on an agarose gel. The fragment pattern identifies the contaminant as M. hyorhinis. Briefly, a PCR reaction is performed with a mix of 9 primers to cover a range of mycoplasma species, including major contaminants of cell cultures. The 500-520 bp PCR products, depending on the species, are then subjected to several digests with restriction endonucleases to differentiate between 7 mycoplasma species, as previously described [14]. Cells were cultured without antibiotic for several days. I ml of supernatant and $\mathrm{I} \mathrm{ml}$ of trypsinized cells were centrifuged for $10 \mathrm{~min}$ at 13,000 rpm and DNA was extracted using DNeasy Blood and Tissue Kit (Qiagen). The PCR was carried out in $50 \mu$ containing $0.2 \mathrm{mM}$ of each deoxynucleotide, $0.2 \mu \mathrm{M}$ of each primer (sequences provided in Ref. [17]), I.5 mM MgCl 2 . PCR conditions were as follows, 5 min denaturation at $95^{\circ}, 35^{\mathrm{cycles}}$ of 30 sec at $95^{\circ} \mathrm{C}, 30 \mathrm{sec}$ annealing at $65^{\circ} \mathrm{C}$ and I min extension at $72^{\circ} \mathrm{C}$ followed by a final extension for $10 \mathrm{~min} .5 \mu \mathrm{l}$ of the PCR products were used for restriction digests in $20 \mu \mathrm{l}$ of reaction volume for $3 \mathrm{hrs}$. The following enzymes were used: Pfl $\mathrm{FI}$ (isoschizomer of Asp I), Bam HI, Hae III, Hpa I, BstBI (isoschizomer of Sfu I) and Xba I. Fragments were analyzed on a I.5\% agarose gel. 
itive APP-transfected HEK293 cells. Interestingly, no A $\beta$ was detected in the conditioned medium of the mycoplasma-positive cells (Figure 3A, lane 2), while these cells strongly overexpressed APP (Figure 3A, upper panel, lanes 1 and 2).

\section{Mycoplasma eradication restored $A \beta$ accumulation in APP-transfected cells}

Successful mycoplasma decontamination can be achieved by treatments with different antibiotics, including quinolones and tetracyclines [9]. Contaminated APP-transfected cells were treated for one week with the quinolonebased antibiotic, MRA (4-oxo-quinolone-3-carboxylic acid derivative). The antibiotic treatment successfully eradicated the mycoplasmas (Figure 3A, lower panel), and restored $\mathrm{A} \beta$ accumulation in the conditioned medium of the APP-transfected cells (Figure 3A, middle panel). $M$. hyorhinis, M. orale, M. arginini, M. fermentans, M. hominis and Acholeplasma laidlawii represent $90-95 \%$ of the contaminants in mycoplasma-positive cells $[12,13]$. By restriction fragment length polymorphism assay of PCR products amplified from a region of the conserved 16S rDNA gene in mycoplasma species [14], we determined that the APP-transfected cells were contaminated with the $M$. hyorhinis species (Figure 3B). Together these results show that mycoplasmas degrade $A \beta$ in cell cultures.

\section{Discussion}

$\mathrm{A} \beta$ peptides are degraded in cell culture systems and in vivo by at least four peptidases from the metallopeptidase family, neprilysin, endothelin-converting enzyme-1 and 2 , and insulin-degrading enzyme [15]. Bacteria express numerous proteases with important biological activities, such as degradation of tissue matrix proteins or activation of zymogens through limited proteolysis. The vast majority of the contaminations in mycoplasma-positive cells are due to $M$. hyorhinis, M. orale, M. arginini, M. fermentans, M. hominis and Acholeplasma laidlawii $[12,13]$. Partial sequencing of the $M$. hominis genome predicted the expression of at least three metallopeptidases, and M. penetrans, a mycoplasma species isolated from human, is predicted to express oligopeptidase O1, a metallopeptidase from the M13 neprilysin family. Here M. hyorhinis was identified in the contaminated APP-transfected cell lines. It is conceivable that $M$. hyorhinis also expresses metallopeptidases with homologies with known mammalian metallopeptidases, which degrade $A \beta$ but not large secreted proteins, such as sAPP $\alpha$. Contamination with mycoplasmas would therefore provide a very efficient peptidase-driven mechanism of $\mathrm{A} \beta$ clearance.

In conclusion, we show that (i) mycoplasmas from cell culture contaminations degrade in vitro $\mathrm{A} \beta$ produced in cell lines, (ii) mycoplasma-positive APP-transfected cells do not accumulate $A \beta$ in the conditioned medium, and (iii) eradication of the mycoplasma contaminant (i.e. M. hyorhinis) by treatments with a quinolone-based antibiotic, restored extracellular A $\beta$ accumulation in APP-transfected cells. Together these results demonstrate that mycoplasmas may represent a significant source of variability when comparing extracellular $A \beta$ levels between different cell lines. We therefore recommend assessment of mycoplasma contamination prior to extracellular A $\beta$ level measurements in cultured cells.

\section{Competing interests}

The authors declare that they have no competing interests.

\section{Authors' contributions}

HZ, UDW, and PM performed experiments. PD and PM discussed the experimental strategy. PM and UDW wrote the manuscript.

\section{Acknowledgements}

We thank Dr. P. D. Mehta (Institute for Basic Research in Developmental Disabilities, Staten Island, NY) for generously providing us with RI antibody. The authors are grateful to Dr. G. Agiostratidou (Albert Einstein College of Medicine, Bronx, NY) for assistance with the MycoSensor PCR Assay Kit.

\section{References}

I. Selkoe DJ: Alzheimer's disease: genes, proteins, and therapy. Physiol Rev 200I, 8 I:74I-766.

2. Hardy J, Selkoe DJ: The amyloid hypothesis of Alzheimer's disease: progress and problems on the road to therapeutics. Science 2002, 297:353-356.

3. Golde TE: The Abeta hypothesis: leading us to rationallydesigned therapeutic strategies for the treatment or prevention of Alzheimer disease. Brain Pathol 2005, 15:84-87.

4. Checler F: Processing of the beta-amyloid precursor protein and its regulation in Alzheimer's disease. J Neurochem 1995, 65: $1431-1444$.

5. Marambaud P, Robakis NK: Genetic and molecular aspects of Alzheimer's disease shed light on new mechanisms of transcriptional regulation. Genes Brain Behav 2005, 4:134-146.

6. Weggen S, Eriksen JL, Das P, Sagi SA, Wang R, Pietrzik CU, Findlay KA, Smith TE, Murphy MP, Bulter T, Kang DE, Marquez-Sterling N, Golde TE, Koo EH: A subset of NSAIDs lower amyloidogenic Abeta42 independently of cyclooxygenase activity. Nature 200I, 4I 4:2I 2-2I6

7. Wolfe MS, Xia W, Ostaszewski BL, Diehl TS, Kimberly WT, Selkoe DJ: Two transmembrane aspartates in presenilin-I required for presenilin endoproteolysis and gamma-secretase activity. Nature 1999, 398:513-517.

8. Xia X, Wang P, Sun X, Soriano S, Shum WK, Yamaguchi H, Trumbauer ME, Takashima A, Koo EH, Zheng $H$ : The aspartate-257 of presenilin $I$ is indispensable for mouse development and production of beta-amyloid peptides through beta-cateninindependent mechanisms. Proc Natl Acad Sci U S A 2002, 99:8760-8765.

9. Uphoff CC, Drexler HG: Comparative antibiotic eradication of mycoplasma infections from continuous cell lines. In Vitro Cell Dev Biol Anim 2002, 38:86-89.

10. Tsai S, Wear DJ, Shih JW, Lo SC: Mycoplasmas and oncogenesis: persistent infection and multistage malignant transformation. Proc Natl Acad Sci U S A 1995, 92:10197-10201.

II. Sokolova IA, Vaughan AT, Khodarev NN: Mycoplasma infection can sensitize host cells to apoptosis through contribution of apoptotic-like endonuclease(s). Immunol Cell Biol 1998, 76:526-534.

12. Hay RJ, Macy ML, Chen TR: Mycoplasma infection of cultured cells. Nature 1989, 339:487-488. 
13. Drexler HG, Uphoff CC: Contamination of cell culture, mycoplasma. Encyclopedia of cell technology Volume I Edited by : Spier RE New York, John Wiley \& Sons, Inc 2000:609-627.

14. Uphoff CC, Drexler HG: Comparative PCR analysis for detection of mycoplasma infections in continuous cell lines. In Vitro Cell Dev Biol Anim 2002, 38:79-85.

15. Turner AJ, Fisk L, Nalivaeva NN: Targeting amyloid-degrading enzymes as therapeutic strategies in neurodegeneration. Ann N Y Acad Sci 2004, 1035: I-20.

16. Marambaud P, Zhao H, Davies P: Resveratrol promotes clearance of Alzheimer's disease amyloid-beta peptides. J Biol Chem 2005, 280:37377-37382.

17. Wirth M, Berthold E, Grashoff M, Pfutzner H, Schubert U, Hauser $H$ Detection of mycoplasma contaminations by the polymerase chain reaction. Cytotechnology 1994, 16:67-77.

Publish with Bio Med Central and every scientist can read your work free of charge

"BioMed Central will be the most significant development for disseminating the results of biomedical research in our lifetime. "

Sir Paul Nurse, Cancer Research UK

Your research papers will be:

- available free of charge to the entire biomedical community

- peer reviewed and published immediately upon acceptance

- cited in PubMed and archived on PubMed Central

- yours - you keep the copyright

Submit your manuscript here:

http://www.biomedcentral.com/info/publishing_adv.asp 